\title{
Julius Mägiste ja Andrus Saareste erialasest koostööst paguluses kirjavahetuse põhjal
}

Julius Mägiste 120

VALVE-LIIVI KINGISEPP

Epistolaarne kirjandus, mis olemuselt on pihtimuslik ja mõtisklev, pakub võimaluse jälgida teadlaste, kirjanike, erinevate kirjutajate mõtteid, arvamusi ja suhtumisi sel ajahetkel, kui kiri on koostatud. Onnelikematel juhtudel on säilinud ka vastuskirjad, moodustunud terviklik või osaline kirjavahetus, dialoog, mis avab üksikasjaliselt kirjade autorite mõttemaailma detaile ja loominguseiku hilisematele lugejatele.

Kuidas suutsid kaks eesti suurt keeleteadlast Julius Mägiste (1900-1978) ja Andrus Saareste (1892-1964) oma erialast tööd jätkata pagulastena Rootsis, sellest saame tänuväärselt üksikasjalikku teavet nende aastatel 1944 kuni 1964 peetud regulaarsest kirjavahetusest, mida säilitatakse Eesti Kirjandusmuuseumi kultuuriloolises arhiivis. Olen neid kirju kasutanud siis (artiklis „Eesti vana kirjakeel Julius Mägiste uurimisalana Lundis”, Kingisepp 2000), kui Rootsist saabunud materjalid paiknesid veel kirjandusmuuseumi keldris ja olid üksikasjaliselt läbi töötamata. Tänu kultuuriloolise arhiivi juhataja Vilve Asmeri abile sai Tartu Ülikooli eesti keele ja üldkeeleteaduse instituut hiljem kirjadest Joel Ilja digiteeritud koopiad ning mul oli au ja rõõm neid kasutada Õpetatud Eesti Seltsi 180. aastapäeva konverentsil 23. XI 2018 peetud ettekandes „Julius Mägiste ja Andrus Saareste kirjavahetusest paguluses”, millele osaliselt toetub järgnev kirjutis.

Kahe eesti suurmehe kirjavahetuses avalduvad nende erilised isikuomadused: väsimatu töövõime, pühendumus, kollegiaalsus, kustumatu missioonitunne olusid trotsides luua, elus hoida rahvuslikku keeleteadust. See on erutav killuke meie kultuurilugu, kurb ja rõõmus ühekorraga.

Mägiste kirju on 68 (EKM EKLA, f 254, m 22:22), Saareste omi 80 (EKM EKLA, f 340, m 30:23). Mägiste kirjad on kõik käsikirjalised, Saareste on osalt kirjutanud käsitsi, osalt trükkinud kirjutusmasinal. Kirjade kuupäevade vormistus on järgnevas ühtlustatud.

\section{Ühenduse teke}

Kirjavahetust alustab Mägiste. Ta esimene kiri Saarestele on kirjutatud 15. novembril 1944 Rostockist, kuhu ta oli Nõukogude okupatsiooni eest põgenedes oma kuueliikmelise perekonnaga jõudnud. Mägiste jutustab hetkeolukorrast, ta kavatseb pere viia kuurortlinna Kühlungsborni, vastusaadressiks annabki sealse hotelli Parsche. 
Ise sõitvat homme (Westermanni?) kutse peale Berliini läbirääkimisele soome-ugri keelte lindistamise asjus, soovib seejärel kohe Greifswaldi tulla ja palub abi korterivõimaluste otsimisel. ${ }^{1}$

Saareste esimeseks sõnumiks on postkaart Uppsalast 29. detsembril 1945: „Saadan katseks selle kaardi, et kuidagi sidet luua. Aadressi ei tea, kuulsin aga, et olete kuhugi siia saabunud. Tere tulemast siis Rootsis ja onnnelikku uut aastat peale mulluste vaevade ja murede."

Mägiste teine kiri on juba Rootsi põgenikelaagrist Homna-Voxnast 12. veebruaril 1946 ja selles pajatab ta temale omasel humoorikal viisil „laisast laagrielust” ja ootab Lundi töölepääsemist. ${ }^{2}$ Saareste sõnumid Mägistele saabuvad Kopenhaagenist, kus ta on ülikoolis eesti keele loenguid lõpetamas:

[---] nüüdsest peale jääb mul töötada omaette (küll teatud koostöös eesti k. alal prof. L. Hjelmslev’iga) ja vabalt, kuidas süda lustib. Jätkan koguni siin Taani pinnal eesti murrete uurimist, kogumist (parandamata viga!) eestlaste laagris, [---] viimistlen atlase ja ideoloogilise sõnaraamatu ning sõnadejärjekorra käsikirju ning kohendan ka unarule jäänud kirjanduse tundmist [---]. Jään siia 1. novembrini [---]. Nagu näed, saadan Sulle ka rea küsimusi Kudina murde kohta. Loodetavasti pole Sa seda unustanud? Hõlbusta vastamist sellega, et märgid otse küsimuslehele! Olen Sulle iga teate eest väga tänulik. (5. VI 1946, EKM EKLA, f 340, m 30:23)

See oli esimene Mägistele saadetud küsitlusleht paljude hilisemate hulgas. Mägiste on varmas oma elu üksikasjadest teavitama 16. juulil 1946 lähetatud kirjaga:

20. maist alates olen siin Lundis nüüd assistentarhiivlane prof. K. G. Ljunggreni juures. Tegelikult olen olnud ka prof. Wieselgreni kasutuses niipalju kui tema mind vajab oma Eesti-rootsi kohanimeuurimuse juures. See abistustöö on päris huvitav. Minu šeff - praegu suvitamas - andis mulle loa uurida vana eesti kirjakeelt, ja nüüd loengi päämiselt XVII saj. Eesti vaimulikku kirjandust, kirjutades säält välja kõike, mis mingit huvi võib pakkuda. Kirjutamist on palju olnud, nii et käekirigi, mis kunagi suur asi pole olnud, käest ära kipub, nagu märkad. Rootsi elemente tolle ajastu eesti kirjakeeles ajan ka taga, niipalju kui mu silm selleks on võimeline. Pikapääle, kui niisuguses rahus töö edasi läheb, võib sellest saada eriuurimus (või mitmeid kirjutisi) eesti kirjakeele ajaloo kohta.

\footnotetext{
${ }^{1}$ Saareste töötas 1944. aastal eraõpetlasena Greifswaldi Põhja Instituudis (Nordisches Institut) (Raag 1997: 7, 455). Kirjandusmuuseumi kultuuriloolises arhiivis on seitse Louis Hjelmslev' prantsuskeelset kirja Saarestele, neist esimene on 13. detsembrist 1944, teine 23. jaanuarist 1945 ja mõlemad saadetud Greifswaldi aadressil Bahnhof-Strasse 33-34, kus Saareste tol ajal oletatavasti pidi viibima (EKM EKLA, f 254, $m$ 19:19, 123/24).

${ }^{2}$ Põgenemistee täpsustuseks lisan, et Mägiste kälimehe Alo Rauna kirjas Saarestele (Hamburg 16. I 1946, EKM EKLA, f 254, m 24:6) leidub märkus: „Mägiste sai Rootsi viisa ja lahkus Hamburgist 18. 12. 45."
} 


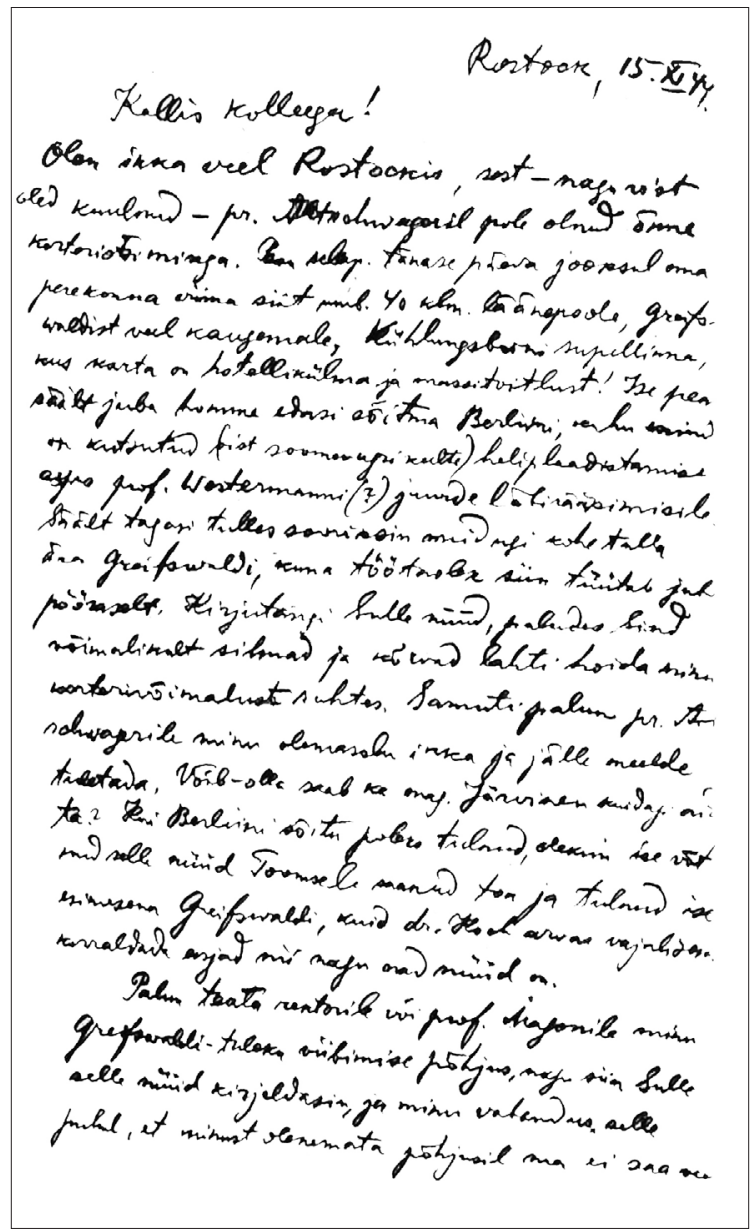

Joonis 1. Julius Mägiste Andrus Saarestele saadetud esimese kirja algusosa (15. XI 1944, EKM EKLA, f 254, m 22:22).

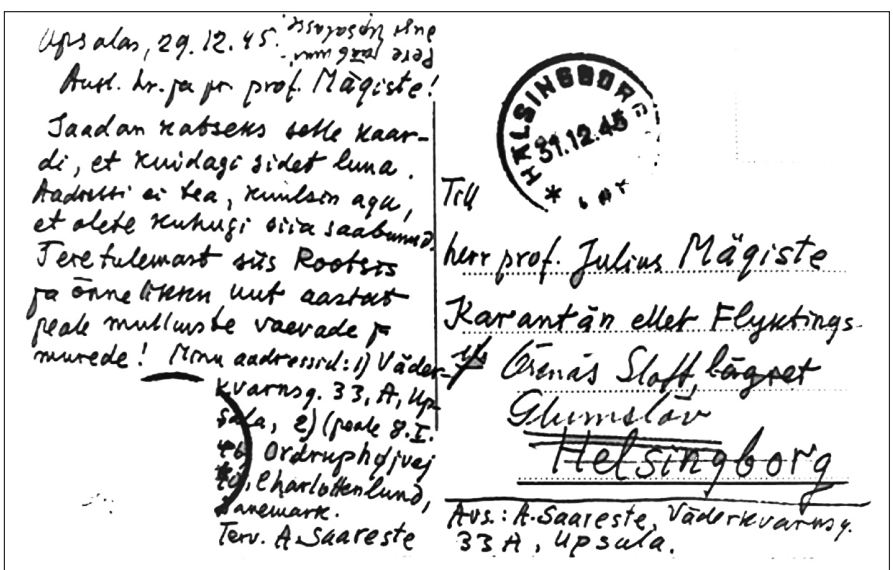

Joonis 2. Andrus Saareste postkaart Uppsalast (29. XII 1945, EKM EKLA, f 340, m 30:23). 
Edasi palub Mägiste infot, mis vanast Rootsi-aegsest eesti kirjandusest on olemas Kopenhaageni ülikooli raamatukogus, et seda Lundi tellida. Ta lõpetab kirja:

Sinu tööd liiguvad praegu puhtalt e. rahvakeele uurimise alal, arvatavasti ma Sulle oma ettevõttega ei jää jalgu. Muid teemasid siin ka kerge leida pole. Seni vähemalt on minu šefid mulle andnud laialise töövabaduse, suurema autonoomia kui moskoviidid Eestile on andnud. (16. VII 1946, EKM EKLA, f 254, m 22:22)

Saareste vastab sama aasta 19. septembril Kopenhaagenist ja kirjeldab seda vähest, mis sealses raamatukogus eesti vanast kirjandusest olemas on, aga lõpetab kirja tähendusrikaste sõnadega:

Soovin Sulle siis avameelselt õnne tööks eesti vanema kirjakeele alal! Et Sa mulle siin kuidagi ,jalgu jääksid”, nagu kirjas tähendad, pole tarvis Sul minust iialgi karta, isegi kui Sa töötaksid murrete alal. Tööväli on meil ju üpris avar ja veel söödis ning töötajaid vähe, siin küünarnukkidega ei saa küll ükski teist tülitada! Võiks vastupidi öelda: seltsis segasem! (tuntud heas tähenduses viimane sõna) (19. IX 1946, EKM EKLA, f 340, m 30:23)

Mõlemad keeleprofessorid süvenevad pagulastingimustes erakordse innukusega erialasesse töösse. Saareste on pärast pagulaslaagreis viibimist saanud augustis 1945 tööd Uppsala murde- ja rahvapärimuste arhiivis, edasi Uppsala ülikooli soome-ugri keelte õppetoolis. 1. juulist 1948 sai ta riikliku eristipendiumi, tööülesandeks eesti murrete uurimine, täpsemalt eesti murdeatlase ja mõistelise sõnaraamatu koostamine. Üksikasjaliselt kirjeldab Saareste tööaastaid Uppsalas Raimo Raag (1997), eluloolisi andmeid pakuvad Saareste kirjad õele (vt Must 1992). Andrus Saareste elu kustus 10. mail 1964.

Mägiste tegevust vana eesti kirjakeele uurimisel olen käsitlenud paaris varasemas kirjutises (Kingisepp 1997, 2000). Mägiste sai pärast pagulaslaagris viibimist esialgu arhiivitööd, peagi järgnesid soome ja ungari keele lektorikursused, hiljem soomeugri keelte kursused Lundi ülikoolis. Aastail 1950-1967, kuni pensionile minekuni oli ta Lundi ülikooli soome-ugri keelte dotsent, soome-ugri keelte seminari juhataja ja sealse suure erialase raamatukogu rajaja. Mägiste uurimistööd iseloomustavaid artikleid ja täpsed andmed ta trükitöödest (üle 450) leiduvad Penti Soutkari (1960, 1975) koostatud bibliograafiates. Julius Mägiste suri 11. märtsil 1978.

\section{Seltsis segasem}

Kahe keeleprofessori uurimisvaldkonnad - Saarestel eesti murded ja Mägistel vana kirjakeel - kujunevadki kokkuleppe kohaselt kummalegi järgneva eluperioodi jooksul paguluses kõige olulisemaiks. Koostööd teevad nad aga mõlemas valdkonnas ja paljus muuski: küsivad nõu eesti sõnade päritolu kohta murretes või kirjakeeles, vahetavad vana kirjakeele mälestisi, mida kummalgi on õnnestunud posti 
teel Soome või Rootsi ülikoolide raamatukogudest hankida, loevad artiklite korrektuure ja analüüsivad avaldatud töid, selle kohta pakub kirjavahetus rikkalikult näiteid. Avameelselt ja vaimukalt jagavad nad oma arvamusi keeleelu kohta Eestis enne Teist maailmasõda ja kaasajal Rootsis, küsivad vastastikku töötingimuste ja uurimisstipendiumide hankimise kohta, arutavad keelekonverentsidel osalemise võimalusi, eesti keele õpetamise algatusi ja käekäiku Rootsi ülikoolides, saatusekaaslaste toimetulekut paguluses jpm. Kultuurilooliselt unikaalset andmestikku on neis dialoogides rohkesti. Järgnevas pühendun peamiselt nende $\mathrm{mu}$ rd e a l a s e koostöö vaatlusele.

Saareste asus paguluses kohe uut keelejuhtide võrku looma, et rahvakeeleainese kogumist ja uurimist jätkata. Ta sai Uppsala ülikooli raamatukogu keldrikorrale tööruumi suure töölaua ja raamaturiiuliga, kuhu kodunt kogu „oma laboratooriumi” üle kandis.

Muidugi, et mu kogud kodumaale jäid, lonkab töö tublisti, aga paremus see, et omal jõul jätkata saan ja kiiremini edenen [---] Kasutan siin ka murret tundvaid inimesi ja niimoodi karistan aegajalt ka sind, kelles õnnelikult ja haruldaselt (nagu Veskiski, aga mitte Ridalas!) on ühinenud keeleteadlane ja keeletark (keelejuht). (27. XII 1946, EKM EKLA, f 340, m 30:23)

Saareste usub, et kodumurde meenutus kolleegile lõbugi pakub:

Järjekorras on jällegi kätte jõudnud Sinu keelemälu kiusamine. Soovin, et see Sulle siiski lõbu pakuks ja Sind silmapilguks nagu armsasse kodukohta istutaks. Jah, mina näen pea iga öösi - kõik need aastad - und, et olen salaja kodumaal, ja nimelt Tallinna tänavail, kus imetlen seal jälle vanade hoonete, milles ju kasvanud, kaunist arhitektuuri. Sellest viimasest on siin ju puudu. (14. V 1951, EKM EKLA, f 340, m 30:23)

Keeletark keelejuht, nagu Saareste endast kaheksa aastat nooremat kolleegi tituleeris, Mägiste tõesti oli. Ta alustas juba üliõpilaspäevil murdeainese kogumist kodukihelkonnas Maarja-Magdaleenas, jätkas Ingeris ja setude juures, kujunedes 1930. aastaiks Akadeemilise Emakeele Seltsi murdekogumistöö uusi eesmärke nägevaks, neid esitavaks, senist tööd hindavaks ja arvustavakski teadlaseks. ${ }^{3}$ Mägiste omaaegne kriitika oli pagulaspäevil teravuse kaotanud, Saareste suutis nende kunagisi omavahelisi eriarvamusi tõeväärselt hinnata - sellest täpsemalt tagapool, kirjas 6. VI 1956.

Mägiste võtab saatusekaaslasest vanema kolleegi palveid kuulda ja tuus J.Mg. läkitab talle üksteise järel sarnase algusega kirju: „Kallis Saareste! Viimaks olen niikaugel, et saan Sulle ära saata viimase küsimuslehe vastused siin ümbrikus. Kõike ju, mis vaja, enam kahjuks ei mäleta" (4. IV 1947, EKM EKLA, f 254, m 22:22) või "Kallis Andrus, vastan kysimused kohe nii ,,iast-kurjast” kui mäletan [---]” (2. V 1950, EKM EKLA, f 254, $\mathrm{m}$ 22:22) koos vastustega, nagu:

\footnotetext{
${ }^{3}$ Sõjaeelsest murdekogumistööst, Saareste ja Mägiste eri seisukohtadest ses vallas on üksikasjaliselt kirjutanud Mart Mäger (1966) uurimuses „Eesti murrete sõnaraamat. Ajalugu, koostamisprintsiibid, väljavaated”, täiendavat infot pakub Huno Rätsepa kirjutis „Tartu ülikooli eesti keele arhiivi saamisloost ja saatusest" (2003).
} 
Päälegi esitasid Sa mulle viimati nii häbematult palju küsimusi (ms perekonnanimesidki veel!), et nende vastamine pole paari päeva küsimus. Saadan Sulle siis nüüd kõik kuidagiviisi vastatult, niivõrra kui mälust ei tulnud puudu. Perek-nimede loendi selgituseks pean ütlema, et see sisaldab endiste Kudina v. piiride nimesid esmajoones, sest minu tihedam kontakt ümbrusega ulatub ju umb. aastaisse 1900-1920 [---] Saad niisiis ühtlasi ka kohanimesid [---] Minu nimestik on niisiis ajalooline, nagu mina isegi olen Kudinale „ajalooline isik”, keda sääl varsti unustetakse, kui mind Kruus jt. sõbrad tagasi ei kutsu oma isaisade talu õigusi tagasi saama. (16. VII 1946, EKM EKLA, f 254, $\mathrm{m}$ 22:22)

Ja siis lõppeks saadan selles ymbrikus ära ka Sinu viimase kysitluskava vastustega ja paari Kudina talu õueplaani [---]. Kustase (minu isatalu) ehitati põhjalikult ümber 1892-1906 vahel, millal uus (telliskivist, reheta) elamu ehitati teisele poole teed (a.1892) ja hiljem tall, „tõllahoone”, aidad ja puukuur ehitati ka sinna. (24. I 1957, EKM EKLA, f 254, m 22:22)

Samas leidub kirjavahetuses vastupalveid ka Mägistelt, näiteks „teata lühidalt kõik, mis sa tead sõna (k)rahmama (või raamama) täh. 'haarama, haarates võtma' esinemise kohta eesti murdeis” (19. XI 1947, EKM EKLA, f 254, m 22:22); „Saada mulle, ole hää mees andmeid kõrnis ja kõrne sõnade levimise kohta eestis!" (26. XI 1951, EKM EKLA, f 254, m 22:22). Kirjas 6. augustist 1953 vastab Saareste Mägiste küsimustele sõnade vaksik; kaster; koost, - $a$; lant, - $u$ tähenduste ja leviku kohta murretes. Nende koostöö sujus ladusalt, vahel aasivaski vormis, küsimuste poolelt oli Saareste innukam, sest vajas konkreetseid andmeid sõnaraamatu tarvis.

Mul tekkis huvi, kas Saareste küsitluslehed oma korrespondentidele on säilinud. Tänu Eesti Kultuuriloolise Arhiivi töötaja Leili Punga abile selgus, et ongi. Fond 254, m 12:3 sisaldab 261 lehte ja on pealkirjastatud „Andrus Saareste vähemaid küsimusi (ja küsitluslehed) aastaist 1929 kuni 1938”. Ja on teine säilik, kokku 15 suurt Saareste küsitluslehtedega kausta, kõik teele läkitatud ja vastatult murdeagentidelt tagasi saadud paguluses (EKM EKLA, f 254, m 36-50). Kaustad on järjestatud kihelkondade kaupa alfabeetiliselt, alustades Ambla ja lõpetades Vändra kihelkonnaga. Näib, et uurijad pole siiani nende vastu suuremat huvi tundnud, tegu on aga ühe kindla allikaga, millele tuginesid Saareste murdeuurimused eksiilis. Lisan, et küsitluskavadest, mis Saareste saatis Eestisse aastail 1957 kuni 1964 ja millele KKI töötajad eesotsas Mari Mustaga vastasid, on teinud ülevaate Helmi Neetar (1992).

Helmi Neetar on loonud konkreetsete arvude abil ettekujutuse Saareste hämmastavast töövõimest ja -pingest vaid ühe materjali, 1958. aasta küsimuslehtede põhjal. Ta kinnitab, et säilitatud vastuslehed võimaldavad jälgida „Eesti keele mõistelise sõnaraamatu” koostamise köögipoolt, selgitada, mis läks vastustest näiteks 1 . köite täienduseks kasutusele, mis ja kui palju jäi välja. Valitud mõisterühma EHAL KÄıMA põhjal kirjeldab ta täpselt, mida Saareste küsis, mida sai vastuseks ja mis kajastub sõnaraamatus.

Kultuuriloolises arhiivis säilitatavates kaustades on muu hulgas Maarja-Magdaleena kihelkonna küsitluslehed ja nende täitjaks peaaegu ainuisikuliselt Mägiste 
(EKM EKLA, f 254, m 42:1). See on muljet avaldav andmekogu! Vastustega lehti, paljud neist mitmeleheküljelised, on kaustas kokku 51, neil keskmiselt 20-30 päringut, mõnel isegi 50-60 masinal tipitud küsimust. Tohutu tippimistöö! Ega asjata kurtnud Saareste ühes kirjas, et käed on „masinal porrutamisest” nii haiged, et kirja kirjutada saab vaid sulega (8. VII 1957, EKM EKLA, f 340, m 30:23). Hiljem mainib ta, et ostis vaeva vähendajaks elektrilise kirjutusmasina. Ühtekokku on Saareste kolleeg Mägistele läkitanud üle 900 päringu ja kui kirjade kuupäevi silmas pidada, on ta neid saatnud pidevalt, sõnaraamatu koostamise käigus vastavalt käsil olnud mõisterühmadele. Nii näiteks küsis Saareste: „Kas rase loom oli tiine?” Mägiste vastus: „Hobune (ainult) oli ram, rā̄ märà jne, jäi rammmast. Lehma kohta lüpsmasāja (harv. vist). Kuuldud ka eufemistlikult (pojà)-tōja lüpssmasāja leHm." (20. XI 1951 küsitlusleht, EKM EKLA, f 254, m 42:1) Saareste küsimus: „Kas oma karjumisega vihma kuulutav lind oli vihmakass või peoleo?“ Mägiste vastus: „Igatahes pole kuulnud peoleo nime murdes, vih̆ma-kas̄ võimalik, kuuldud - kas oma sõnana või võõrana, ei tea. Harilik vihma-ennustaja oli kōvittaja meil." (3. VI 1960 küsitlusleht, EKM EKLA, f 254, m 42:1) Või Saareste küsimus: „Kas kohupiima tehti?” Mägiste vastus: „Tehti, aga mis ajast saadik, ei tea öelda. Minu lapsepõlves igatahes meie peres see polnud populaarne toit. Mäletan enam paks su p̂̂ma (paks p $\hat{I} m$ ), mis polnud nii tihe ja kuiv kui kohupiim, aga millest vesi oli välja nõristet ja millele mu ema koort sekka segas, nii et see hästi süüa kõlbas." (10. XI 1961 küsitluslehe 8. küsimus, EKM EKLA, f 254, m 42:1)

Kiireks on läinud 1950. aastate lõpus, näiteks küsitluslehel 18. IX 1959, kus 19 masinakirjas küsimust, on Saareste käsikirjaline märkus: „Kibe rutt vastustega, trükikoda ootab!" (EKM EKLA, f 254, m 42:1) Kõikidele küsimustele pole muidugi vastust leidunud, aga ka mingi tähenduse või vormi esinemuse eitus on vajalik vastus. Paljudele küsimustele on Mägiste lisanud oma seletusi, täpsustusi, jooniseid. Vastused on enamasti ikka foneetilises transkriptsioonis. Viimane küsitlusleht vastustega on Lundist teele saadetud 22. jaanuaril 1964, Saareste surma-aastal. See on materjal, mida Saareste vajas oma sõnaraamatu viimastes vihikutes sisalduvate mõisterühmade kohta ja mis oli märgendiga „Rutuline! Rutuline!” (EKM EKLA, f 254, m 42:1) Kui Maarja-Magdaleena kihelkonna küsitluslehtedel leiduvat infot sama tähelepanelikult ja üksikasjaliselt uurida, nagu eespool mainitud uurimuses tegi Helmi Neetar, saaks täpse pildi Mägiste mõttetööst, ta omakasupüüdmatust abist Saarestele murdeväljaannete loomisel paguluses. Saareste pole tänusõnadega kitsi ja kirjutab:

Ja eriti südamest aitäh nende rohkete ning põhjalikkude keeleliste andmete ja nimede loetelu eest! Neist oli mulle töös suur kasu. (19. IX 1946, EKM EKLA, f 340, m 30:23)

Oma keelekorrespondente ja keelejuhte pean harilikult ikka ise korrale kutsuma, neile omalt poolt nende õiget vana murret meelde tuletades. Sina aga nähtavasti oled ainus, kus mul seda vaja pole. Et aga sõnavara küsimustele ei saa alati positiivselt vastata, pole imestada. Need on ju need jäänused, need kõige kõvemad pähklid. (17. XI 1947, EKM EKLA, f 340, m 30:23) 
Kõik ligi 230 keelejuhti koos kodukohamärgendiga on esitatud sõnaraamatu indeksi lõpus, Mägiste nende seas (Saareste 1979: 492). Kultuuriloolises arhiivis säilitatavad 15 kausta küsitluslehtedega, mis Saareste on kogunud kõikide eesti murrete kohta paguluses, ootavad tänaseid murdeuurijaid allikakriitilist analüüsi tegema, täpsustamaks „Eesti keele mõistelise sõnaraamatu” lähtematerjali.

Mägiste ei keeldu abist isegi siis, kui Saareste oma agaruses keeleainestiku hankimisel palub Mägistet koguni osaleda kihnlastest keelejuhtide küsitlemiseks fonografeerimisretkel Lõuna-Rootsi Halmstadi. Retke korraldas Saareste kolleeg litsentsiaat Broberg. Saareste soovitab sõbral küsitleda naisi, sest meestel on Kihnus hoopis „üldlaadsem keel”. Ta juhendab, et ained olgu mis tahes, hea, et oleksid sisult mitmekesised ja valgustaksid Kihnu eluolu: kalapüük, hülgepüük, vanade rahvariiete kirjeldus, naiste käsitööd, kangaspuude üksikud osad, kodused tööd, põllutöö ja heinategu, ebausukombed, naljalood jne. „Ja mida enam tekste suudad neilt välja pigistada, seda parem.” (5. IX 1950, EKM EKLA, f 340, m 30:23) Mägiste leiab, et kihnlastega kontakti saamine oleks „hää asi”, kurdab aga liigsete majanduskulude pärast, tagasisõit ja ööbimine, mida ta oma suure pere tõttu ei saa lubada, samas on ta nõus kolleegi põhimõtteliselt abistama (7. IX 1950, EKM EKLA, f 254, m 22:22). Vastuskirjas tunnistab Saareste, et mõistab sõbra kartust sõidukulude pärast, aga arvab, et soovi korral sõidutab Broberg ta fonografeerimisretkelt õhtuks Lundi tagasi (11. IX 1950, EKM EKLA, f 340, m 30:23). Küllap olukord nii laheneski.

Kui Saareste on saanud murdeatlase koostamisega lõpusirgele, teatab ta, et peale 128 kaardi sisaldab atlas veel tekstigeograafiat, nimelt sama teksti 26 eri murdes. Ta on ise koostanud loo ja selle tõlkinud eri murdeisse.

Aga see meetod pakub ainust võimalust anda edasi murrete erinevat ilmet, kogupilti /nagu isiku erijoonte kirjelduse kõrval tema pilt/ ja võimaldab võrdlemist. Ligemas tulevikus seda teha on juba võimatu. Tulemust tuleb muidugi võtta cum grano salis ja vastutus langeb minu õlgadele, kui kedagi leidub, kes vääratusi leiab. Siia kaasa lisan Sulle ühiskeelse põhiteksti, ehk oled nii lahke ja leiad kord aega see tõlkida mulle oma kodumurdesse, mis aga muidugi enam ei saa tulla atlasesse. (1. I 1955, EKM EKLA, f 340, m 30:23)

Sellegi soovi täidab sõber, tuus J.Mg.

Eesti professorite eneseteostus paguluses ei olnud kaugeltki kerge ja kui kaasmaalane soovitud vastust kaua oodata lasi, libises Saareste kirjadesse ka etteheitvat tooni:

Sina ju mõistad mind: kui inimene on pidanud maha jätma suurema osa ligi oma 30 aastase töö viljast, aga ometi tahab ja on otsustanud maksku mis maksab oma kohust täita ja oma tööd kõige kiuste jätkata, kui ta nüüd kitsais oludes ja väga lühikese aja jooksul püüab siin puuduvast vähemalt olulistki restitueerida, andmeid pärides Rootsist, Taanist ja Saksast tülika ja vaevarikka kirjavahetuse teel (kusjuures vastutulek ja abi ka ses viimases maas on otse imetletavasti soe ja andmeid kokku voolab ootamata häid ja rohkesti) ning ligimas ümbruses pühapäeviti suuliselt sõõrutades, 
siis on mulle, mõistad küll, pisut kibe, kui just Sinult neid teateid mulle sõõrub vahest korra aastas. Ja ometi peab mu käsikiri edasi minema. Valgete kohtade rohkus aga senises osas on väga tülikas ja segab edaspidise osa viimistlemist, sest igalt poolt tuleb ju viita [viidata - V-L. K.] ette ja taha. (12. X 1947, EKM EKLA, f 340, m 30:23)

Kümmekond päeva hiljem kirjutatud vastuses selgitab Mägiste üksikasjaliselt oma töid-tegemisi ja kaitseb end vapralt. Ta jutustab, et saanud stipendiumi, tuli tal iga kuu aru anda ja tunda end armuleivasööjana. Suvel olnud ta kaks kuud Värmlandis ja Norras, kus küsitlenud 40 soome keele kõnelejat, ja asunud ainestikku puhtaks kirjutama ja töötlema; redigeerinud, tõlkinud ja trükivalmis seadnud ligi 200 lehekülge vadja tekste, ja lõpetab:

Nii et tööst pole puudu ka siinpool. Sellepärast pole ka alati aega ja põgenikuoludes ka mitte alati lustigi kirjutada. Sinu etteheited minule lohaka kirjutamise pärast olid põhjendatud, kuid kui Sinu enda kirjutamisfrekventsi ja vastamistihedust (mulle vähemalt) arvestada, siis muutub see õigustatus küsitavaks. Kui aga midagi Kudina keele kohta vajad, kirjuta. Katsun vastata edaspidigi nii kuidas aeg ja olud lubavad. Ma ei taha jääda süüdlaseks, kui mõni koht Sinu kaartidel jääb valgeks. Aga eks too vana murre hakka mulgi ununema, nii et minust „kistagu” (<kes teab kui) suurt kasu pole. (22. X 1947, EKM EKLA, f 254, $\mathrm{m}$ 22:22)

Ajapuudusest hoolimata vastab Mägiste Saareste pikkadele ja üksikasjalikele küsimustele järjekindlalt, kohusetruult ja rikkalike seletustega, osutades kolleegile hindamatut inimlikku abi paguluse kitsastes tingimustes.

\section{Mõttevahetus sõnaraamatu sisu ja väljaandmise teemal}

Üsna kirjavahetuse algusest selgub, et Saareste kavandas kapitaalset sõnaraamatut vihikute kaupa välja anda. „Olen mõelnud ka juba teose trükkimist kusagil vihikute kaupa, sest teose iseloomu kohaselt pakub ju iga peatükk, seega ka iga vihik tervikut." (1. V 1947, EKM EKLA, f 340, m 30:23) Sama mõtet avaldab ta kümme aastat hiljem, kui teatab, et mustandis ja paljugi täiendusi nõudval kujul on ta sõnaraamatuga jõudnud $\ddot{u}$-täheni:

Aga millal on sõnaraamat täielik? Olen selle asjaga üldse õnnelik ja õnnetu, töö on väga huvitav, kuid ühele mehele liig, kipub ülejõu. Mõtlen aga juba siiski tasapisi, 2-3 poognaliste vihikute kaupa ilmutama hakata, et vähemalt autor ise saaks algust näha ja sellele mingit suunda anda, et kogu asi ükskord mitte kopitama ei jääks. Võõral ju raske teise musta pesu vaalida. (29. I 1957, EKM EKLA, f 340, $m$ 30:23)

Kuidas õnnestub lahendada keerukaid trükkimismuresid, saavutada kokkulepe kirjastusega Vaba Maa jpm, kõike seda saame kirjadest lugeda. Visa töö tulemusest teatab Saareste kolleegile, et esimese vihiku jaoks on tal pool, s.o neli trükipoognat 
juba puhtaks kirjutatud ja palub Mägistet, et ta käsikirja enne trükki minekut läbi vaataks. Saareste täpsustab, et sõber pööraks tähelepanu lühendamistele lausenäiteis, liitsõnade näiteis ja tähenduse seletustes. Enesekriitiliselt tunnistab ta, et teda kiusab elus alati „ebajärjekindluse kurat” (1. VIII 1957, EKM EKLA, f 340, m 30:23). Saareste soovib veel, et Mägiste kui asjatundja avaldaks oma arvamuse sõnaraamatu laadi ja sisu kohta, rõhutaks, et see ei ole mitte harilik kuivavõitu sõnaraamat, vaid pakub pilti kogu meie rahva praegusest ja eriti muistsemast elust, annab otse huvitavat lugemisvaragi. Ta toonitab, et ideoloogilised sõnaraamatud on üldsusele vähe tuttavad ja seni pole veel keegi usaldanud neid koostada säärasel kujul (lähedane on siiski lapi oma). „Sõnu tähestikuliselt esitada on võrdlemisi lihtne, täbaraks muutub aga mõisteliselt. Siin palju oleneb autori mõtteviisist ja maitsest." (1. VIII 1957, EKM EKLA, f 340, $\mathrm{m}$ 30:23)

Mägiste loeb korrektuuri, teeb oma tähelepanekud, „notiitsid”, nagu ta neid nimetab, ja saadab need kolleegile. Valminud vihikute kohta kirjutab ta tagasihoidlikult:

Lähen päevakorras edasi sellega, et saatsin Sulle täna Su Sõnaraamatu vihud 2., 3. ja 4. oma segaste märkustega, mis pole ei systemaatsed ega hästi loetavadki (on tehtud mul enda tarbeks muidugi), aga võib-olla et midagi kasutatavat leiad neist. (6. V 1959, EKM EKLA, f 254, $m$ 22:22)

Kui teos on kunagi tervelt ilmunud, siis võib-olla mõneks vähemaks korrektsiooniks või täienduseks võiks olla minu sikerdusist kasu. Nii et jäägu need märkmed parem ootama teose lõppköite ilmumist. (9. XI 1961, EKM EKLA, f 254, m 22:22)

Saareste vastuskirjad on täis tänusõnu märkuste eest ja ta lubab kõike tõsiselt kaalumisele võtta, välja arvatud Mägiste kriitika tüvevahelduse esituse kohta, mida ta lubab sõnaraamatu eessõnas seletada ja põhjendada.

Lausenäited on, nagu nad mul käepärast on, olen mustandist valinud paremad ja iseloomulikumad. Mis siis viga, kui mul oleks kõigilt kirjanikelt ja ka rahvakeelest täielikud, täpsemalt rikkalikud tsitaatide kogud. Olen aga alati pidanud tööd tegema enam-vähem üksinda. (16. VIII 1957, EKM EKLA, f 340, m 30:23)

Kirjavahetuses avaldab Saareste soovi, et Mägiste võtaks kogu sõnaraamatu korrektuuri enda peale, sest „paremat, täpsemat, asjatundlikumat inimest” ta ei tea. Ta arutleb poognatasugi üle, mida saaks ehk väljaandjalt kaubelda, aga Mägiste soovib jääda oma uurimuste juurde ja aidata kolleegi jõudumööda vaid sõbrana.

Täna sain postilt välja lunastada ka Sinu sõnaraamatu 3. vihu. Asi rõõmustavalt edeneb, materjal on rohke ja huvitav, nagu kõik ootasidki. Ainult korrektuuri peaks suurteosele vastava tähelepanuga loetama, trükivigu on rohkesti ja mõnikord segavaidki. Ja aine järjestust võiksid tarvitajate huvides ikka veel kaaluda, samuti ka korrektsemat astmevahelduse jms. (gen. infin.) edasiandmist. Muidu mu parimad jõusoovid töö jätkamiseks. (31. X 1958, EKM EKLA, f 254, m 22:22) 
Trükivigade põhjusi seletab Saareste järgmiselt: „Et trükikulud on viimseni madalaks kaubeldud, saan ainult kahte korrektuuri nõuda, mis hoopis loomuvastane säärases töös. Eriti palju vigu tegi rootsi laduja. Nüüd on eestlane, osav ja hoolas mees, asi kohe parem, aga rootsi murdjaga on raskusi." Hiljem selgub, et eestlasest laduja osutus alkohoolikuks, kes vajas ravi. „Kardan väga, et mees mokka läheb - siis tuleb jälle rootslast harjutama hakata ja vigade rohkusega uuesti maadlema hakata. Nii on need olud.” Edasi toob ta „kuratliku näite” 1. vihikus leiduvast veast. „Ei mõista, kuidas see võis sündida pärast minu revisjoni. Hea, et mu juuksed olid juba enne hallid - ehk lähevad nad selle tööga viimaks mustaks! Arvesta siis meie pagulasolusid, anna kõik andeks ja katsu mu küsimustele varsti vastata." (13. IV 1960, EKM EKLA, f 340, m 30:23)

Teatades, et 17. vihik on ladumisel, tunnistab Saareste:

Sul on kirjas ka õigus, et võiksin hoolikam olla. Aga pean tõttama, ajaga võidu jooksma. Mul on alati ees valik, dilemma: 1) kas olla veelgi põhjalikum, hoolsam - ja seega ehk paraku tööga pooleli jääda (kes viitsiks seda lõpetada?) või: 2) jätkata praeguse tõtliku tempoga, mille tagajärjed jätavad mõndagi soovida (seda tean ise kõige paremini). (Dateerimata kiri, EKM EKLA, f 340, $m$ 30:23, 177/83p)

1963. aasta 12. augustil lähetatud kirjas teatab Saareste, et on leidnud sõnaraamatule indeksi tegija, prantslase, keeleteadlase, iseõppija ja tundmatu, kes on paljude Euroopa väikeste keelte kõrval „kätte õppinud ka soome ja päris ühegi eestlase abita ka eesti keele", kellega Saareste pidas eestikeelset kirjavahetust ja kes rääkinud päris ladusat korraliku sõnavaraga eesti keelt. „See on küll haruldane lind, aga prantsuse faunas neid ja sääraseid leidub."4 (12. VIII 1963, EKM EKLA, f 340, $m$ 30:23)

Üsna kirjavahetuse lõpuosas teatab Saareste dateerimata kirjas: „Maiks saan omalt poolt 18. vihu, seega siis ka 3 . köite ilmutada. Nii siis oleks $3 / 4$ tööd selja taga." (EKM EKLA, f 340, m 30:23, 1 80/86) Mägiste viimane kiri, samuti dateerimata, teatab talle omase tagasihoidlikkusega: „[---] et mitte vastamist „kalevi alla” lasta minna, saadan Sulle kohe ära kiiruga kirjutet vastused Sinu kysimusile. Palju Sul minust küll abi pole, sest kodumurde mälestused nihkuvad minust igapäev kaugemale." (EKM EKLA, f 254, m 22:22, 156/58)

Asjalikku nõu pakkus Mägiste Saarestele 1961. aasta kevadel Hööris puhkust veetes, teatades, et ajakirja Mana toimetaja Ivar Grünthal on tellinud temalt kolleegi sõnaraamatu ilmunud osade (II köite kahe algusvihu) põhjal tutvustuse ja tal on käsikiri valmis, pakub lugeda. „Lisan etymoloogilisile pisimärkmeile ette mõningaid soovitussõnu Su teosele, vahest sest on kasu nii Sulle kui kirjastusele ilmumisvõimaluste huvides." (EKM EKLA, f 254, $m$ 22:22) Ja kuna Mägiste oli oma pagulusaja algusest peale intensiivselt uurinud vana eesti kirjakeelt, tundis-teadis kirjakeele sõnade esmaesinemust vanades tekstides, nõudis ta sõnaraamatu „ainestiku deskriptiivis-sünkroonilisel esitamisel” suuremat „keeleajaloolis-diakroonilist

\footnotetext{
${ }^{4}$ „Eesti keele mõistelise sõnaraamatu” sissejuhatuses tänab Saareste indeksi ehk sõnajuhataja koostamisel abiks olnud abikaasat, tundmatut prantslast mainimata (Saareste 1958: XIV). Ka ei nimeta teda indeksi trükkitoimetaja Johannes Raag (1979).
} 
valvsust”, tõi näiteid silma hakanud eksitustest ja ebatäpsustest, näiteks sõnade korv, kurre 'halva, nõrga kuulmisega', kokutama jt kohta (Mägiste 1961: 96).

Saareste sõnaraamatu viimaseid vihikuid (21. ja 22.) ta eluajal viimistleti ja trükiti, kuid tegija oma tööd tervikuna ei näinud, selle toimetas trükki kaaspagulane Valter Tauli. Paguluses valminud suurejooneline keeleline mälestusmärk „Eesti keele mõisteline sõnaraamat”, tõeline Monumentum Estoniae Antiquae ilmus neljaosalisena aastail 1958-1963.

\section{Tagasivaateid keeleelule. Mineviku varjud}

Kahe suure keeleuurija omavahelised töösuhted paguluses olid enamasti sõbralikud, teineteist toetavad ja mõistvad. Seda kinnitavad paljud kirjakohad, näiteks Saareste Mägistele: „On üldse väga rõõmustav, et nüüd siin paguluses vähemalt meie 3-4 keelemehe vahel puuduvad vastuolud (mis ei tarvitse tähendada meelsuse erinevuste puudumist) ja et vahekorrad on nii sõbralikud" (24. II 1956, EKM EKLA, f 340, m 30:23).

Ja hinges kantud salajasigi muresid poetasid nad kirjaridadesse. Kätte oli jõudmas Saareste 60. sünnipäev ja ta kurdab Mägistele:

[---] mul on tuline hirm oma eelseisva „ümmarguse” sünnipäeva eest! Ma ei salli tervituskõnesid endale ja mulle on vastik vähegi suuremas seltskonnas olla tähelepanu märklauaks. Neid päevi olen varemalt veetnud põgenemisega maale, külasse, kord isegi Liivi. Loodan, et see kujuneb vaikseks (nüüd põgenemiseks puudub raha), ja rohkemalt ma kedagi ei kutsu, peale paari vana hea sõbra ja kolleegi. Kui siis Sinagi juhtud juuni 3. nädala kesk- või lõpupaiku sõitudel olema kuskil ligikonnas, siis astu palun lahkesti minu poole sisse, näeksin Sind heameelega ja räägiksime vanust ja nüüdseist asjadest! (7. V 1952, EKM EKLA, f 340, $m$ 30:23)

Mägistest Saareste koduse peo külalist ei saanud, aga ta kulutas palju aega ja energiat juubelikirjutiste koostamiseks ja mõjutas, et juubeliks ilmuks trükist Saareste uurimus „Kaunis emakeel. Vesteid eesti keele elust-olust” (1952). Juubeliartiklites tunnustab Mägiste kolleegi töö üksikasju ja olulisust ajastu kontekstis. Sõbra elutööst kõige põhjalikum kirjutis ilmus Orbises (Mägiste 1956). Kirjavahetusest selgub, et Mägiste andis teksti korrektuuri eelnevalt Saarestele lugeda, kes tegi sellesse omapoolseid parandusi, mis Mägiste trükiväljaandes arvesse võttis. Pikemas kirjas põhjendas Mägiste oma seisukohti:

Selle kirjutisega nägin tüki vaeva, nagu võid arvata, ja see oli tehtud mitte ainult sõprusest, vaid esmajoones just rahvuslikust kohusetundest, et näidata meil tehtud keeleteaduslikku tööd muudele ja Sinugi tegevust käsitella üldse meie keeleteadusliku töö tausta vastu. Katsusin vähemalt seda teha ausalt ise-enda ja eriti Sinu vastu, oma meelest sellesama aususe ja siirusega, millega ma siis, kui minu kirjutises käsiteldud töö palavikuliselt käis, Sinuga tihtipääle põhimõtteliste küsimuste pärast polemisee- 
risin, veel paremaid saavutusi taotlevaid vastuettepanekuid tehes. Loodan, et Sa nüüd tagantjärele sellest kõigest eriti hästi aru saad ja mõistad, et minu korduvad hääletõstmised murdeuurimise käigu alal olid asja huvides tehtud, niisama nagu nüüd tagantjärele tulemusi üle vaadates on asja ja meie ühise töö huvides, et nähakse kõike seda positiivset, mis on tehtud, ega tagantjärgi ei targutata selle üle, mis oleks võinud teha, et meie vahel siis oleks valitsenud niisama sõbralik teineteisest arusaamine kui nüüd. Kirjutan seda sellepärast, et tõrjuda Sinu märget korrektuuril, et ma vahest olen Sinu teeneid liiga kõrgelt hinnanud. (1. VI 1956, EKM EKLA, f 254, $m$ 22:22)

Vastuskirjas selgitab Saareste arvamuste seisu omalt poolt:

Ära Sa pane pahaks, kui ma kiiruga oma väikesi tänusõnu korrektuuri lõpus ehk mitte kõige õnnelikumalt ei stiliseerinud. Sinu artikli suur väärtus esmajoones on muidugi eesti teaduse tutvustuses, seda teadagi konkreetsuse kaudu. Ja Sul pole vaja karta, et südames mingit okast kannaksin, et Tartus tehtud murdekogumist arvustasid ja suuremaid nõudeid esitasid. ${ }^{5}$ Hindan alati kriitikat ja opositsiooni, ilma milleta miski ei sugene. Sain aga teha muidugi oma suutmise piirides ja antud aineliste võimalustega. Hindan ja tunnustan täiel määral Sinu õiglaselt mõeldud avitavat osa ses töös. Aga eks me mõlemad olnud vanasti sagedasti ka päris ägedad mehed? Raplesime aga siiski asjade endi pärast, mitte aga isiklikult ja puhtast pahurusest, nagu nüüd mõni sell siin paguluses. (6. VI 1956, EKM EKLA, f 340, m 30:23)

Otseste keeleküsimuste kõrval uurib Saareste oma kirjades sõbralt teavet minevikus juhtunu kohta, täpsemalt muutustest murdeuurimisel pärast tema kõrvaletõrjumist AES-i tööst Saksa okupatsiooni päevil. Ta kirju läbib mure, äng ametist vallandamise pärast, ja ta kirjeldab ning mõistab hukka Oskar Looritsa avalikke rünnakuid, milles Okuloru teda kommunistiks tembeldab, silmas pidades 1941. aastal ajalehtedes ilmunud üleskutset valimistele (Arumaa jt 1941) ja murdeuurimise aruande puhul antud usutlust (Saareste 1941). Selge ülevaate eesti murdeuurimise keerukatest probleemidest kahe okupatsiooni aastail pakub Huno Rätsepa (2003) eespool mainitud uurimus.

Saareste kirjutab: „Meie ühine „sõber” Oku on viimasel ajal täiesti marru läinud” - ta on koostanud taas avaliku kirja Saareste laimamiseks ja Saareste ähvardab avaldada vastuseletuse ning dokumendi Oku enda tempude kohta.

\footnotetext{
${ }^{5}$ Mägiste soovis murdetoimkonna koosolekul (20. V 1937), et AES-i murdekogumine muutuks järgneva viie aasta jooksul rahvakeele-sõnaraamatu ainestiku kogumise hoogtööks, et muud kõrvalised kogumissuunad (Saareste huvil tekkinud mõistelise küsitlemise, murdetekstide avaldamise ja keeleatlase koostamise tööd) viidaks miinimumi, koguja töötaks püsivalt samal murdealal, keelejuhte valitaks nõudlikumalt, hoolikamalt jälgitaks sõnade tähenduslikku külge, kaalutaks kogude kopeerimist, ühtlustataks transkriptsiooni põhimõtteid, selgitataks sõnaraamatu väljaandmise tehnilisi küsimusi, tutvutaks vastava tööga mujal, seltsi teadussekretär seotaks praktilise murdekogumistööga, AES-i juhatus valiks viieliikmelise rahvakeele-sõnaraamatu toimkonna. (Mäger 1966: 606) Paljud Mägiste ettepanekud hiljem realiseerusidki.
} 
Nii-kui-nii mees on 10 a. sosistades laimanud, tulgu siis asi nüüd päevavalgele. Mu intervjuust „Plv-s” on mul õnneks koopia, tõin selle kaasa Soomest. Seal on see peaaegu õieti, aga teistes komm.-aegseis lehtedes see oli iga üh es e rivi is il ja nende tuntud kõvade sooladega. Kui õiendada tahtsin, naerdi mind välja. Vajaksin aga ka muud O. L. paljastuseks või vähemalt selle mehe musta iseloomu valgustuseks. (1. IV 1955, EKM EKLA, f 340, $m$ 30:23)

Saareste uurib selgitust kuulduse kohta, nagu oleks Loorits käinud sakste või punaste ajal August Annisti peale kaebamas, kui Annist oli pandud ülikoolis tema asemele rahvaluule loenguid lugema. Mägiste püüab vastuskirjades omalt poolt selgitusi jagada niivõrd, kuivõrd tema aastatetaguseid sündmusi mäletab. Kirjas 5. IV 1955 imestab Mägiste, et Okuloru jälle kempleb. Ei tea, kas saavat Nõukogude Liidu saatkonnast tasu, et nii agarasti kõiki teisi punaseks tembeldab? Annisti tagakiusamise kohta tal otse fakte pole ja soovitab küsitleda Imant Rebast, tolleaegset tudengit, keda Loorits „tegudele innustanud”.

Üks Mägiste pikk vastuskiri selgitab üksikasjaliselt väljapääsmatut olukorda, millesse keeleprofessorid „vabatahtlikult” juunipöörde järel 1941. aasta jaanuaris sovetliku riigikorra valimiskampaaniasse tõmmati (vt Arumaa jt 1941).

Looritsa sõimukampaaniat olen ajakirjandusest muidugi pahameelega jälginud ja õnnistanud seda, et elan säält Upsala-Stockholmi pesast nii kaugel ja seetõttu suhtelises rahus. Looritsa jutt sellest, et meie teaduskonnamehed oleksid vabatahtlikult andnud oma õnnistuse 1941. a. jaanuarivalimisele oma üleskutsega, on häbematu loba, mida ta ka ise ei usu. Mäletan asjade käiku õige selgelt. Ühel jaanuari algupäevil tuli prorektor Koort „Verneri” kohviku teise toa paremas, kaugeimas nurgaloožis minu juurde salajutule ja ütles, et valimiskampaania on käimas ja iga teaduskond peab Kure nõudel andma avalikult oma poolduse, sellest pääsu ei ole. Meie teadusk. ajaloolasedfilosoofid (teaduskond koosnes ju siis kahest osast - ajaloo+keeleteaduskonnast!) olevat oma seletuse juba alla kirjutanud ja Kure olevat meie keeleteaduskonna-osale väga kuri. Tema ise muidugi polnud sugugi kuri, vaid oli hädas ja ütles, et Kure on käskinud temal selle asja korraldada ja et meie keeleteadlased peavad selle kõige lähemal ajal koostama ja politrukile Ilmar Kruusile Üliõpilasmajas edasi andma. Koordi korraldusel siis kutsuti ühel õhtupoolikul Akad. Emakeele Seltsi ruumides, kui sellel ametlik tööaeg läbi, kokku meie koosolek. Telefoniteel vist või kuidas lepiti enne kokku, et kolm teaduskonna liiget koostavad üleskutse kavandid, mille põhjal siis kollektiivselt koostame üleskutse (Suits, Oras ja allakirj.) Kui kokku tulime, oli kaks visandit tehtud - minul ja Suitsul, kuna Oras ütles, et tema on õhtupooleuinakult just enne koosolekut ärgand ega pole saand midagi kirjutada. Minu paarilauseline visand loeti ette ja Suits tähendas: „See on nii irooniline, et paistab läbi, sellega me ei või välja minna.” Kombineerisime siis kõik koos Suitsu diplomaatilist visandit, mille päämotiiviks oli üliõpilaste ja õppejõudude üleskutsumine valimiste puhul „sotsialistlikule võitlusele" ja selle siis AESi masinal Julius Mark oma käega kirjutas lõpuks puhtaks ja minule tehti ülesandeks see politrukile edasi viia, mida ka politruki varjatud muige (olin ju ise ametisse kinnitamata jäetud prof. k. t.!) all teisel päeval tegin. 
Põikasin teel politruki juurde ülikooli lektooriumi ja seal olid parajasti onu Veski ja Loorits. Näitasin neile käes seda „dokumenti” ja ütlesin irooniliselt: „Kas soovite ka alla kirjutada? Näe, teil pole seda vaja, olete sellest vabad, aga vaadake, mis kõik meilt nõutakse!" Vastust ei oodand neilt ega tulnud. Kahju, et Veskit pole siin, ta võiks sedagi pisistseeni kinnitada. Mis muide lektorite ja muude „alamate” õppejõudude vabastamist tookordsest allakirjutamisest puutub, siis arvan, et ka mul selles on teeneid. Koort kohvikus arvas, et kõik õppejõud peaksid alla kirjutama, kuid mina ütlesin temale kui vanale sõbrale „ausalt ja otsekoheselt” à la Leaurou, et seda küll pole vaja - parem kui minimaalne arv inimesi, kes mööda ei pääse, end sellega määrib. Ja Koort leppis sellega, nagu tal ikka kombeks oli leppida. Mis Kure selle kohta pärast ütles, ma muidugi ei tea. Nii et Loorits allakirjutamisest ei pääsend sugugi enda mehelikkuse või mõne muu talle külgesündimata vooruse tõttu. - Kirjutan selle Sulle asjaolude värskenduseks kui absoluutselt tõepärase mälestuskillu tookordseist keerulisist situatsioonidest. Osalt saad seda ju vajaduse korral siinsete kolleegide (eriti Suitsu) abil kontrollida. Loodan, et Sa ei lähe seda kusagil avalikult nii ettevaatamatult kasutama, et mõni vastaspoolt seda - nagu meil on siin kombeks - ära ei vääna ja meid veel suuremaiks „kommunistideks” ei tee kui me oleme! Meid oli tookord pool tosinat meest koos ja me rääkisime täiesti usalduslikult ja kommunismivastaselt muidugi umbes samas stiilis kui too mainitud Suitsu lause minu kohta, mis minu „vaimutööd” riivavana on mulle isiklikel põhjusil meelde jäänud. (12. V 1952, EKM EKLA, f 254, $m$ 22:22)

\section{Lõpetuseks}

Julius Mägiste ja Andrus Saareste ligi 20 aastat paguluses kestnud kirjavahetus pakub üliväärtuslikku teavet sellest, kuidas erialast tööd otsinud ja leidnud keeleprofessorid oma ideaale, elu mõtet teostasid, missugustes tingimustes tegutsesid, missuguste probleemidega kokku puutusid, kuidas enda ja saatusekaaslaste elu- ja peremuresid lahendasid. Neis kirjades on isikliku kõrval väga palju üldinimlikku, arusaamist oma kohustest konkreetsetel ajahetkedel, eeskuju väärivat murdumatut töömoraali. Saareste kirjast Mägistele:

Minul igatahes on kõik üpris hea, õnn jätkata oma ja rahvuslikku tööd, sest kui on kaotatud kodumaa, sealne töö ja amet, keelekogud ja raamatukogud, siis ei tohi endalt lasta enam riisuda seda viimast, oma tööd ja eluülesannet, oma vaimu ja huvisid. (17. XI 1947, EKM EKLA, f 340, m 30:23)

Eestlaste praegusaja põlvkonnad peaksid saama seda kirjavahetust tervikväljaandena lugeda, et paremini mõista paguluses kõigi hädade kiuste teoks saanud keeleuurimuste kaalu eesti kultuuriloos.

Iänan Juhan ja Madis Mägistet abi eest isa elutöö tutvustamisel. 


\section{ARHIIVIALLIKAD}

Eesti Kirjandusmuuseum, Eesti Kultuurilooline Arhiiv (EKM EKLA):

f 254 - Andrus Saareste

f 340 - Julius Mägiste

\section{KIRJANDUS}

Arumaa, P.; Mark, Julius; Mägiste, J.; Oras, A.; Ränk, G.; Saareste, Andrus; Suits, G. 1941. Üleskutse. - Eesti Keel ja Kirjandus, nr 1, lk 5.

Kingisepp, Valve-Liivi 1997. Julius Mägiste elutöö ühest tahust. - Keel ja Kirjandus, nr 10, lk 661-673.

Kingisepp, Valve-Liivi 2000. Eesti vana kirjakeel Julius Mägiste uurimisalana Lundis. - Julius Mägiste 100. (Tartu Ülikooli eesti keele õppetooli toimetised 15.) Tartu: Tartu Ülikool, lk 183-204.

Must, Mari 1992. Andrus Saareste kirjad Erika Saarestele. - Keel ja Kirjandus, nr 6, lk 367375; nr 9, lk 558-569.

Mäger, Mart 1966. Eesti murrete sõnaraamat. Ajalugu, koostamisprintsiibid, väljavaated. Keel ja Kirjandus, nr 10, lk 602-611; nr 11, lk 663-669.

Mägiste, Julius 1956. Prof. Dr. Andrus Saareste und die Erforschung der estnischen Sprache. - Orbis: Bulletin international de linguistique générale et de documentation linguistique, kd 5, nr 1-2, lk 278-289.

Mägiste, Julius 1961. Märkmeid „Eesti keele mõistelise sõnaraamatu” puhul. - Mana, nr 1, lk 95-98.

Neetar, Helmi 1992. „Eesti keele mõisteline sõnaraamat” (EKMS) ja murdekeel. - Keel ja Kirjandus, nr 6, lk 350-355.

Raag, Johannes 1979. Eessõna. - Andrus Saareste, Eesti keele mõistelise sõnaraamatu indeks. Uppsala: Finsk-ugriska institutionen, $1 \mathrm{k}$ 7-8.

Raag, Raimo 1997. Andrus Saareste Uppsalas. - Keel ja Kirjandus, nr 7, lk 455-467.

Rätsep, Huno 2003. Tartu ülikooli eesti keele arhiivi saamisloost ja saatusest. - 200 aastat eesti keele ülikooliõpet. 1803 eesti ja soome keele lektoraat Tartu ülikoolis. Juubelikogumik. (Tartu Ülikooli eesti keele õppetooli toimetised 25.) Koost Valve-Liivi Kingisepp. Tartu: Tartu Ülikool, lk 153-170.

Saareste, Andrus 1941. Tagasi on tulnud töörõõm ja töötahe. - Tartu Kommunist 11. I, lk 6.

Saareste, Andrus 1952. Kaunis emakeel. Vesteid eesti keele elust-olust. Lund: Eesti Kirjanike Kooperatiiv.

Saareste, Andrus 1958. Sissejuhatus. - A. Saareste, Eesti keele mõisteline sõnaraamat. Kd I. (Eesti Teadusliku Seltsi Rootsis väljaanne 3.) Stockholm: Vaba Eesti, lk IX-XV.

Saareste, Andrus 1958-1963. Eesti keele mõisteline sõnaraamat. Kd I-IV. (Eesti Teadusliku Seltsi Rootsis väljaanne 3.) Stockholm: Vaba Eesti.

Saareste, Andrus 1979. Eesti keele mõistelise sõnaraamatu indeks. Uppsala: Finsk-ugriska institutionen.

Soutkari, Penti 1960. Julius Mägisten julkaisut vuosina 1922-1960. - Vironseppo. Juhlakirja Julius Mägisten 60-vuotispäiväksi 19. 12.1960. Helsinki: Kotikielen Seura, lk 115-133. 
Soutkari, Penti 1975. Julius Mägisten julkaisut vuosina 1961-1970. - Finsk-ugriska smaskrifter, nr 3, lk 30-36.

Valve-Liivi Kingisepp (snd 1935), Tartu Ülikooli emeriitdotsent (Jakobi 2-423, 51005 Tartu), valve@neti.ee

\section{On professional correspondence between Julius Mägiste and Andrus Saareste when in exile: Julius Mägiste 120}

Keywords: exile, correspondence, linguistics, dialectology, informants

The article describes the correspondence between two language professors of the University of Tartu before the Second World War, Julius Mägiste (1900-1978) and Andrus Saareste (1892-1964), which lasted for nearly two decades in exile from 1944 to 1964. There are 68 letters from the former Finnic professor Mägiste and 80 from the Estonian professor Saareste. The letters are kept at the Cultural History Archives of the Estonian Literary Museum (EKM EKLA, f 254, $m$ 22:22; EKM EKLA, f 340, $m$ 30:23).

After staying in refugee camps both professors found jobs in Swedish universities: Mägiste as associate professor of Finno-Ugric languages at Lund, Saareste as a special scholar at Uppsala. The topics of the correspondence are diverse and culturally valuable, providing information on how the two linguists, having sought and found professional work in exile, went on fulfilling the purpose of their lives, on their working conditions, on problems they encountered and much more.

The focus of the article is on the letters eloquent of professional collaboration between the two linguists, mainly revealing Mägiste's advice and help in the completion of Saareste's writings on Estonian dialects. Highlighted are Mägiste's role as a language informant, his contribution in collecting Estonian dialect material, his responses to the questionnaires, but also the evaluations of Saareste's linguistic work in the anniversary writings carrying weight for foreign readership, as well as explanations of certain past events worrying the colleague etc.

The correspondence of Julius Mägiste and Andrus Saareste reveals special features of their characters such as tireless working, commitment, collegiality, an indelible sense of mission keeping them creative in face of circumstances in their attempt to practice Estonian linguistics in exile, despite having lost their homeland, their previous jobs, their language collections and libraries. And yet the spirit, the will to work and the interests of life so far were preserved. The present generations of Estonians should certainly be able to read a full publication of this correspondence leading to a better understanding of the importance of linguistic studies completed in exile in the history of Estonian science.

Valve-Liivi Kingisepp (b. 1935), University of Tartu, Associate Professor emeritus (Jakobi 2-423, 51005 Tartu), valve@neti.ee 